\title{
C-Ring expanded analogs of doxanthrine: conformation plays a critical role
}

\author{
Alia H. Clark, Juan Pablo Cueva, John D. McCorvy, Aubrie A. Harland, \\ Val J. Watts, and David E. Nichols* \\ Department of Medicinal Chemistry and Molecular Pharmacology \\ School of Pharmacy and Pharmaceutical Sciences \\ Purdue University, West Lafayette, IN 47907 \\ E-mail: drdave@purdue.edu
}

\begin{abstract}
To assess the importance of conformation and placement of the $\beta$-substituent of agonist ligands targeted to the $\mathrm{D}_{1}$ dopamine receptor, $( \pm)$-trans-6,6a,7,8,13,13a-hexahydrobenzo[e]chromeno [3,4-b]azepine-2,3-diol 5 and $( \pm)$-trans-6,6a,7,8,9,13b-hexahydrobenzo[d]chromeno[3,4b]azepine-2,3-diol 6 were synthesized as ring-expanded analogues of the high affinity $\mathrm{D}_{1}$ dopamine receptor selective agonist doxanthrine, using a novel tetrahydrobenzazepine ringforming strategy. Compounds $\mathbf{5}$ and $\mathbf{6}$ had only micromolar affinity at the $\mathrm{D}_{1}$ receptor. Molecular modeling show deviations in the orientation of the accessory phenyl ring between 4 and its ring expanded analogs 5 and $\mathbf{6}$. Furthermore, the additional methylene group in the azepine ring may cause an unfavorable steric intrusion into the receptor binding process. These conformational differences suggest that the placement of the accessory phenyl ring must be well defined.
\end{abstract}

Keywords: Dopamine D1, agonist, conformation

\section{Introduction}

Dopamine neurotransmission is instrumental in mediating many neural processes that underlie key behavioral and cognitive functions. ${ }^{1-3}$ In continuing efforts to understand the ligand determinants of dopamine receptor activation, we have focused on the development of ligands selective for specific dopamine receptor-isoforms. ${ }^{4}$ We have been especially interested in developing agonists showing preference for the $\mathrm{D}_{1}$-like receptors, and several of these compounds have shown remarkable pharmacology both in vitro and in vivo. ${ }^{5}$

$\mathrm{D}_{1}$ dopamine selective agonists have been demonstrated to possess profound antiparkinsonian effects in the MPTP-lesioned monkey model of Parkinson's disease, ${ }^{6}$ underscoring the importance of this receptor in the control of motor function. $\mathrm{D}_{1}$ receptor 
activation in the prefrontal cortex has been shown to be essential for cognitive functions such as working memory and attention. ${ }^{7}$ As such, $\mathrm{D}_{1}$ agonists have been proposed as treatments for working memory deficits in patients with schizophrenia. ${ }^{8}$ Reward phenomena also are thought to be dependent upon CNS dopamine receptor activation. ${ }^{9}$ For example, dopamine $\mathrm{D}_{1}$ receptor stimulation decreases cocaine-seeking behavior in rodents. ${ }^{10}$ Increasing awareness of the physiological importance of this receptor subtype has motivated us to develop new ligands with improved affinity and selectivity that might ultimately be developed as novel therapeutic agents.

We have previously shown that attaching an aromatic moiety at the $\beta$-position of dopamine 1 (Chart 1) can confer $D_{1}$ selectivity by enhancing affinity at this receptor while reducing affinity at $\mathrm{D}_{2}$-like receptors. ${ }^{11,12}$ Thus, the design of agonist ligands for the $\mathrm{D}_{1}$ receptor has been largely centered on the synthesis of compounds containing this key structural feature. ${ }^{12-15}$ This strategy, partially motivated by the discovery of the high affinity $\mathrm{D}_{1}$ partial agonist SKF38393 $2,{ }^{16}$ led to the synthesis of dihydrexidine 3 , the first high potency $D_{1}$ selective full agonist, ${ }^{12}$ which incorporates the $\beta$-phenyl moiety as part of its tetracyclic benzophenanthridine skeleton.<smiles>NC=[C]c1ccc(O)c(O)c1</smiles>

1, dopamine<smiles>Oc1cc2c(cc1O)[C@H]1c3ccccc3CN[C@@H]1CO2</smiles>

4, doxanthrine

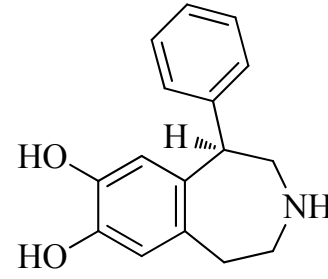

2, SKF38393<smiles>Oc1cc2c(cc1O)[C@H]1Cc3ccccc3CN[C@H]1CO2</smiles>

5<smiles></smiles>

3, dihydrexidine<smiles>Oc1cc2c(cc1O)[C@@H]1c3ccccc3CCN[C@H]1CO2</smiles>

6

\section{Chart 1}

The differential effect on binding that results from $\beta$-phenyl substitution in these dopamine analogues argues for the existence of an important region in the $\mathrm{D}_{1}$ receptor binding site that can accommodate this ring, a feature commonly referred to as the accessory binding site. Some scrutiny of this region of the $\mathrm{D}_{1}$-binding site has been conducted by rational examination of the conformational nature of ligands bearing this substitution. ${ }^{17}$ Nonetheless, observations regarding the conformation of compounds with high affinity for the $\mathrm{D}_{1}$ receptor subtype have generated some debate as to the required directionality and positioning of the $\beta$-phenyl substituent for high affinity binding and functional activation of the receptor. ${ }^{18}$ 
Molecular modeling studies of the high affinity $D_{1}$ ligand SKF38393 2 have shown the positioning of the $\beta$-phenyl moiety in this compound to be relatively flexible. ${ }^{19}$ Calculation of its lowest energy conformations revealed preferred positioning of the $\beta$-phenyl ring planes in either an orthogonal or a coplanar relationship with respect to the catechol ring plane. ${ }^{20}$ No rigid analogues of this compound that retain agonism have been prepared, so it has not been possible to define precisely its active binding conformation.

Calculated low energy conformations of the high affinity $\mathrm{D}_{1}$ agonist dihydrexidine 3 place the relatively conformationally restricted $\beta$-phenyl ring plane at an angle of approximately $56^{\circ}$ above the plane of the catechol ring. ${ }^{12,21}$ This observation has led to the hypothesis that ligands which contain $\beta$-phenyl moieties that approximate near coplanarity with the catechol ring have high receptor complementarity, and thus have higher affinities than those where the ring is placed more axially. ${ }^{17}$ Indeed, this hypothesis has been validated by conformational analysis of several newer compounds that have shown high affinity for the $\mathrm{D}_{1}$ receptor. Given the flexibility and high affinity of compounds like SKF38393 2, however, it is conceivable that the accessory binding region in the receptor binding site can tolerate the presence of bulky groups at angles deviating significantly from that of dihydrexidine 3.

Recently, we reported the synthesis and preliminary pharmacological evaluation of doxanthrine 4 (Chart 1), a chromanoisoquinoline-based bioisostere of dihydrexidine 3 that displayed high selectivity and full agonism at $\mathrm{D}_{1}$ receptors. ${ }^{22}$ The synthetic approach we used to construct the doxanthrine ring system allowed facile access to various $\beta$-substituents, and we envisioned that an increase in $\beta$-substituent volume and flexibility could serve to probe the directionality and/or steric constraints of the $\beta$-phenyl accessory binding region. In this report we describe efforts that led to novel molecules $\mathbf{5}$ and $\mathbf{6}$, which, although they ultimately proved inactive, supported our hypothesis that the accessory phenyl ring must be positioned in a relatively constrained area.

\section{Results and Discussion}

\section{Chemistry}

We envisioned the construction of the previously unreported fused tetrahydrochromenobenzazepine 5 using methodology similar to that employed in the synthesis of doxanthrine $4 .^{22}$ The synthesis of 5 is based on a key diastereoselective conjugate addition of heteroatom-promoted laterally lithiated $o$-tolyloxazoline $\mathbf{7}$ to nitroalkene $\mathbf{8}$.

Nitrochromene 8 was prepared as reported previously ${ }^{22}$ by a one-step procedure involving conjugate addition of sesam aldehyde to nitroethene, generated in situ. In the course of this work we discovered that $\mathrm{O}$-acetylation of sesamol prior to formylation provided the required phenolic sesam aldehyde pure, and in good yield.

$o$-Tolyloxazoline 7 was prepared from $o$-toluic acid using standard procedures. ${ }^{23}$ This oxazoline lithiates laterally upon addition of $s-\mathrm{BuLi}$ and undergoes rapid conjugate addition to 
nitrochromene 8, affording exclusively the desired trans-adduct $\mathbf{9}$ in good yield. Mild hydrolysis of the oxazoline ring of this intermediate led to formation of ester 10, which was then reduced with zinc metal and acetic acid to afford amine 11. Microwave heating of this amine in ethylene glycol led to the intramolecular cyclization of $\mathbf{1 1}$ to lactam 12, which was readily reduced with diborane to produce tetrahydrobenzazepine 13. Treatment of this amine with boron trichloride afforded the desired catecholamine hydrochloride 5 (Scheme 1).<smiles>Cc1ccccc1C1=NC(C)(C)CO1</smiles>

7<smiles>O=[N+]([O-])C1=Cc2cc3c(cc2OC1)OCO3</smiles>

8

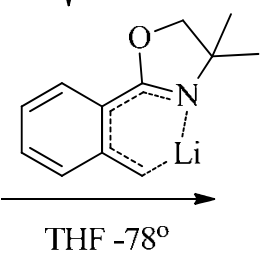

THF $-78^{\circ}$

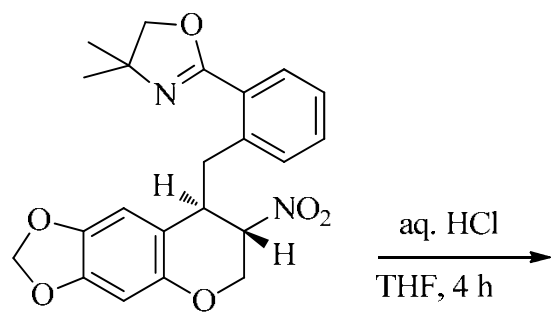

$\operatorname{trans}(+)-9$<smiles>CC(N)(Cl)COC(=O)c1ccccc1C[C@H]1c2cc3c(cc2OC[C@H]1[N+](=O)[O-])OCO3</smiles>

10

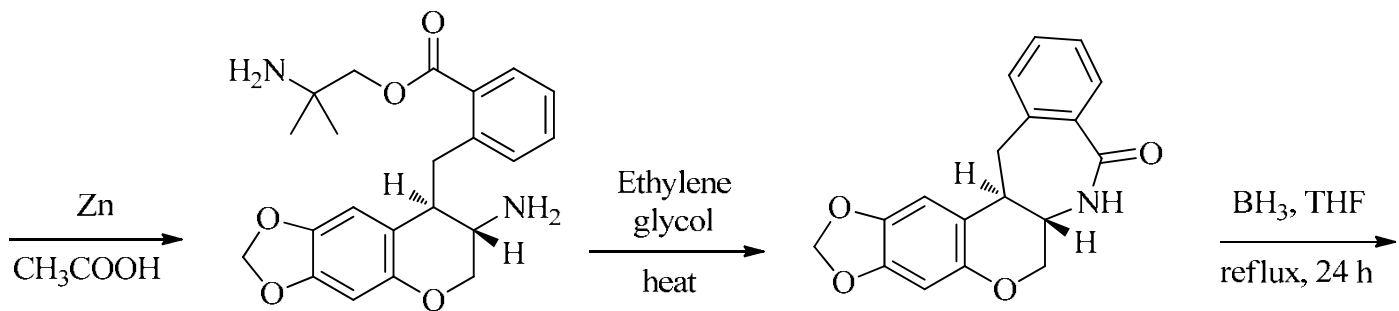

11

12<smiles></smiles>

13

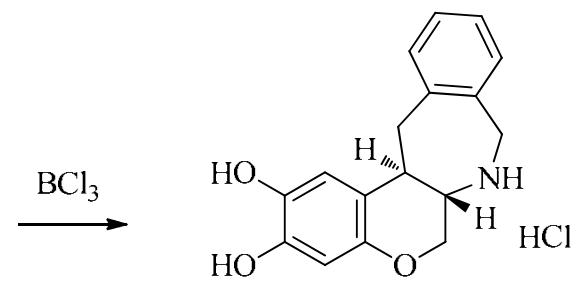

5

Scheme 1. Synthesis of hexahydrobenzo[e]chromeno[3,4-b]azepine-2,3-diol hydrochloride 5.

The synthesis of 6 employed a similar approach, but this molecule proved to be much more difficult to obtain. Dioxolane $\mathbf{1 4}$ was first prepared from commercially available 2- 
bromophenylacetic acid using previously established procedures. ${ }^{24}$ Addition of nitrochromene 8 to the lithiated acetal 14 gave the desired trans-adduct 15. Removal of the acetal moiety under mild acidic conditions afforded the corresponding aldehyde, which was immediately oxidized with an aqueous solution of sodium chlorite in a mixture of potassium dihydrogen phosphate and hydrogen peroxide to provide the desired acid 16. Esterification of $\mathbf{1 6}$ followed by reduction of the nitro moiety gave the amino ester 18, which underwent cyclization in the presence of sodium methoxide to afford lactam 19. Reduction of lactam 19 with diborane followed by cleavage of the methylenedioxy protecting group afforded the target compound $\mathbf{6}$ (Scheme 2).

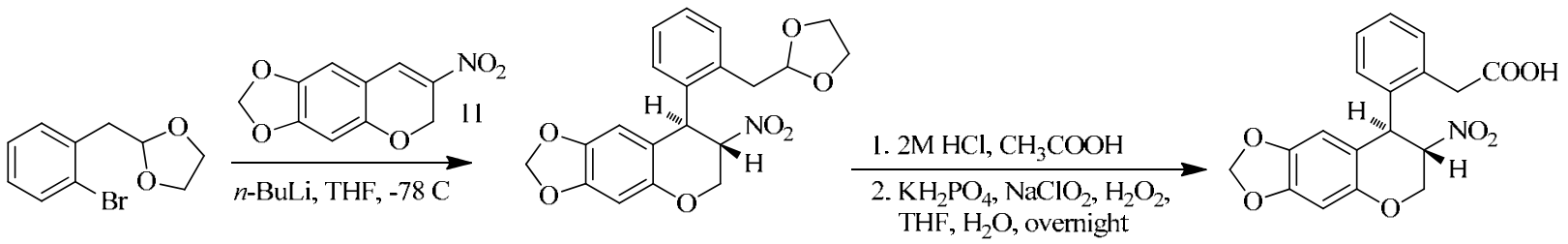

14

( \pm -trans-15

16

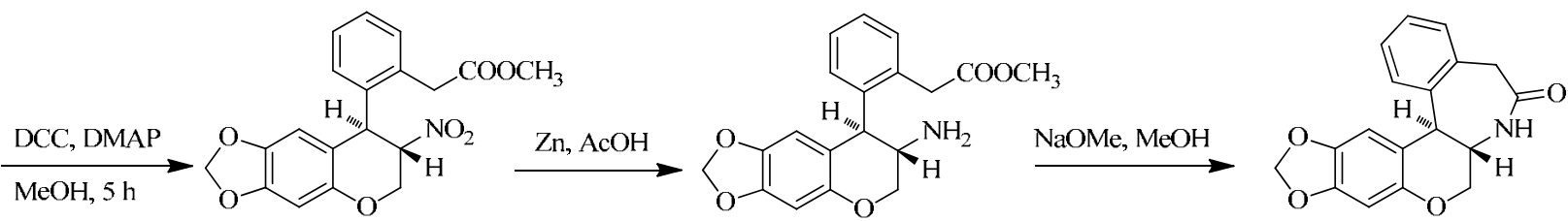

17

18

19

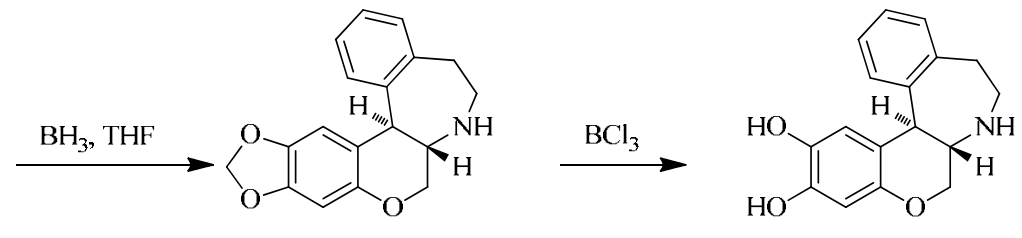

20

6

Scheme 2. Synthesis of hexahydrobenzo[d]chromeno[3,4-b]azepine-2,3-diol hydrochloride 6.

\section{Pharmacology}

Compounds 5 and 6 were compared with doxanthrine 4 for affinity at $\mathrm{D}_{1}$-like and $\mathrm{D}_{2}$-like receptors in pig striatal homogenate. ${ }^{22}$ The $\mathrm{D}_{1}$-like receptor affinities were determined using $\left[{ }^{3} \mathrm{H}\right] \mathrm{SCH} 23390$ displacement, and $\mathrm{D}_{2}$-like receptor affinities were obtained using displacement of $\left[{ }^{3} \mathrm{H}\right]$ spiperone with added ketanserin to mask $5-\mathrm{HT}_{2 \mathrm{~A}}$ sites.

Competition binding experiments show a greater than 150-300-fold decrease in affinity of 5 and 6 for the $\mathrm{D}_{1}$ receptors when compared to doxanthrine 4. Conformational analysis of ligands 5 and 6 reveals significant differences in their conformations, as well as placement of the annelated benzene ring, compared to 4 . The inability to superimpose the $\beta$-substituents of 4 and its 
analogues 5 and 6, anticipated by the ring expansion, makes evident that the loss of affinity of 5 and 6 must be related to conformational and steric effects of the benzazepine ring formation and the annelated benzene ring. In the pseudo-chair conformation of 5, which is the minimum energy conformer, the benzazepine benzene ring plane is positioned almost parallel to, but approximately $2.2 \AA$ above the catechol ring plane. Superimposition of ligands $\mathbf{4}$ and $\mathbf{5}$ clearly shows a significant difference in the directionality of the $\beta$-bulk: whereas doxanthrine projects its $\beta$-benzene ring plane at a $53^{\circ}$ angle $\left(\tau_{1}\right)$ from the catechol ring plane, compound 5 projects its analogous bulk in an equatorial direction, approximately parallel to, but more distal from the catechol ring. From the low binding affinity of 5, it is apparent that bulk projected in this direction is not tolerated by the $\beta$-phenyl accessory region of the binding site.

Table 1. Affinity at porcine striatal homogenates (nM)

\begin{tabular}{ccc}
\hline \multicolumn{1}{c}{ Ligand } & $\mathrm{D}_{1}$-like $\mathrm{K}_{\mathrm{i}}$ & $\mathrm{D}_{2}$-like $\mathrm{K}_{\mathrm{i}}$ \\
\hline Doxanthrine, $\mathbf{4}$ & $21 \pm 4$ & $6120 \pm 1460$ \\
$\mathbf{5}$ & $3240 \pm 615$ & $14220 \pm 3000$ \\
$\mathbf{6}$ & $6970 \pm 1200$ & $16500 \pm 3200$ \\
$\mathrm{SCH}-23390$ & $0.47 \pm 0.05$ & $\mathrm{ND}$ \\
Chlorpromazine & $\mathrm{ND}$ & $67.7 \pm 1.7$ \\
\hline
\end{tabular}
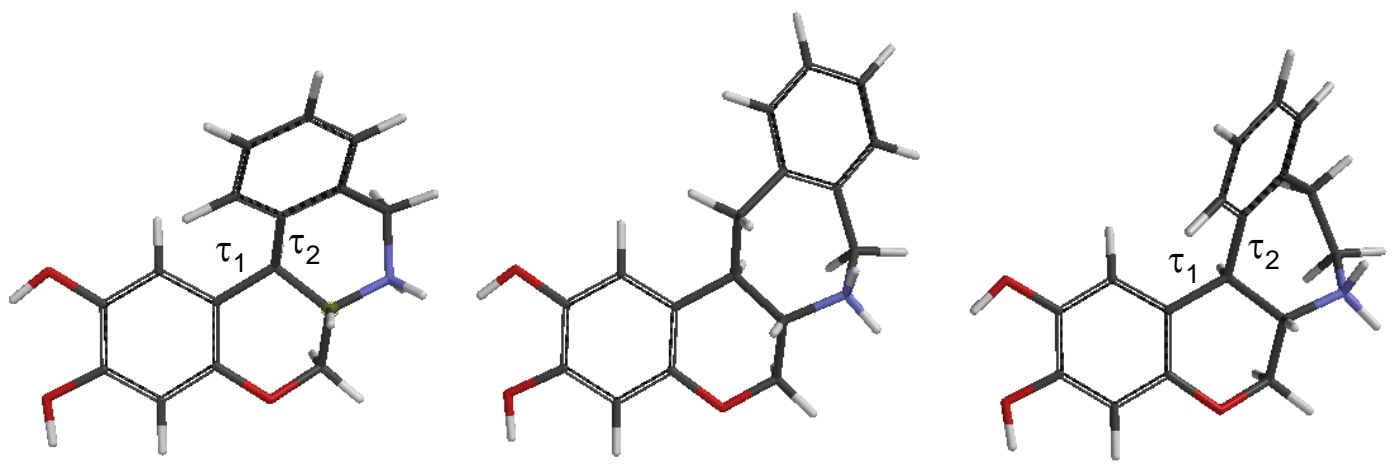

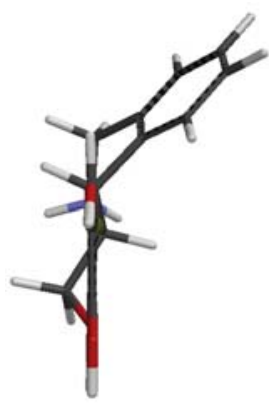

4

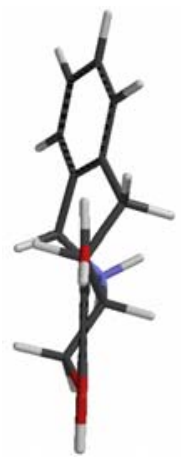

5

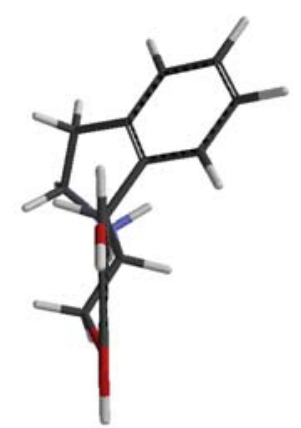

6

Figure 1. Comparison of conformations of compounds 4, 5, and 6. 
Compared to the significant change in the location and conformation of the $\beta$-phenyl in $\mathbf{5}$, the orientation of the annelated phenyl ring in 6 deviates less from that of $\mathbf{4}$. In $\mathbf{4}$, the phenyl is simply displaced upward from the plane of the catechol ring $\left(\tau_{1}=53^{\circ}, \tau_{2}=3.7^{\circ}\right)$, whereas in 6 the aromatic ring is not only displaced upward $\left(\tau_{1}=46^{\circ}\right)$, but also is twisted $\left(\tau_{2}\right)$ approximately $27^{\circ}$. It is possible that the larger twist angle in $\mathbf{6}$ may force the $\beta$-phenyl ring out of a position for favorable aromatic pi-stacking interactions with residues surrounding the $\beta$-phenyl accessory region that is believed to play a crucial role in receptor binding.

Another possible factor for the loss of activity may be the steric consequences of the benzazepine ring in 5 and $\mathbf{6}$ as compared to the analogous 6-membered ring in $\mathbf{4}$. The introduction of an extra methylene moiety not only increases the volume of the ring, but also affects the orientation of the ethylamine side chain. In $\mathbf{4}$, the amino group is approximately in the plane of the catechol ring, whereas in 5, it is displaced upward about $2 \AA$, which would displace it away from the conserved aspartate in helix 3 of the $\mathrm{D}_{1}$ receptor. Although the amino group of 6 also lies approximately in the catechol ring plane, the ethyl tether between the amine and the phenyl ring projects downward (toward the left side in the bottom panel of the figure), and also would be expected to interfere with binding between the amino and the conserved aspartate.

In summary, the conformational differences between compound $\mathbf{4}$ and its analogues $\mathbf{5}$ and $\mathbf{6}$ clearly show the importance of the $\beta$-substituent orientation for $D_{1}$ dopamine receptor interactions. The loss of affinity for compounds $\mathbf{5}$ and $\mathbf{6}$ suggests that the range of accessory phenyl ring conformational variability tolerated by the receptor may be very limited. The increased steric bulk of the azepine ring also may be intruding into a receptor excluded volume within the $D_{1}$ receptor. The loss of activity for both 5 and $\mathbf{6}$, relative to $\mathbf{4}$, may result from a combination of these factors.

\section{Experimental Section}

\section{Chemistry}

General. All reagents were commercially available and used without further purification unless stated otherwise. Flash column chromatography was carried out using silica gel having a particle size of 40-65 $\mu \mathrm{m}$. Melting points were determined in open capillaries with a Meltemp apparatus. ${ }^{1} \mathrm{H}-\mathrm{NMR}$ spectra were obtained using a $300 \mathrm{MHz}$ Bruker ARX-300 spectrometer or a $500 \mathrm{MHz}$ Bruker DRX-500 spectrometer. Mass spectra were obtained by the Purdue University Campuswide mass Spectrometry Center.

\section{4,4-Dimethyl-2-(2-(((7S*,8R*)-7-nitro-7,8-dihydro-6H-[1,3]dioxolo[4,5-g]chromen-8-yl) methyl)phenyl)-4,5-dihydrooxazole (9). 2-(o-Tolyl)oxazoline $7^{23}$ (7.87 g, $41.57 \mathrm{mmol}$ ) was dissolved in dry THF $(150 \mathrm{~mL})$ and cooled to $-78^{\circ} \mathrm{C}$. Into this flask was introduced a solution of $s$-BuLi in cyclohexane $(1.4 \mathrm{M} ; 32.7 \mathrm{~mL}, 45.73 \mathrm{mmol})$, turning the solution a deep crimson color. In a separate flask, nitrochromene $\mathbf{8}^{22}(6.0 \mathrm{~g}, 27.12 \mathrm{mmol})$ was dissolved in dry THF (250 $\left.\mathrm{mL}\right)$}


and cooled to $-78{ }^{\circ} \mathrm{C}$. After stirring at $-78^{\circ} \mathrm{C}$ for $1 \mathrm{~h}$, the lithium reagent was cannulated into the flask containing the nitrochromene, which was held at the same temperature. This mixture was stirred for $15 \mathrm{~min}$, then quenched with water, and allowed to warm to room temperature. More water was added, and the mixture was extracted several times with DCM. The extracts were combined, washed once with brine $(50 \mathrm{~mL})$, dried over $\mathrm{MgSO}_{4}$, filtered, and the solvents were removed under reduced pressure to yield a dark oil. Silica gel flash column chromatography, eluting with hexanes/EtOAc 4:1, provided $9(8.22 \mathrm{~g}, 73.8 \%)$ as an oil that crystallized on standing, and which could be easily recrystallized from EtOH; mp 117-120 ${ }^{\circ} \mathrm{C}$. ${ }^{1} \mathrm{H}$ NMR (300 $\left.\mathrm{MHz}, \mathrm{CDCl}_{3}\right): \delta 7.98(\mathrm{~d}, J=7.5 \mathrm{~Hz}, 1 \mathrm{H}, \mathrm{ArH}), 7.49-7.35(\mathrm{~m}, 2 \mathrm{H}, 2 \mathrm{ArH}), 7.22(\mathrm{~d}, J=7.5 \mathrm{~Hz}$, $1 \mathrm{H}, \mathrm{ArH}), 6.70(\mathrm{~s}, 1 \mathrm{H}, 4-\mathrm{H}), 6.41(\mathrm{~s}, 1 \mathrm{H}, 9-\mathrm{H}), 5.93,5.90\left(\mathrm{ABq}, J_{\mathrm{AB}}=1.5 \mathrm{~Hz}, 2 \mathrm{H}, 2-\mathrm{H}_{2}\right), 4.85$ $\left(\mathrm{dt}, J_{1}=12.6 \mathrm{~Hz}, J_{2}=2.1 \mathrm{~Hz}, 1 \mathrm{H}, 6-\mathrm{H}_{\mathrm{a}}\right), 4.73(\mathrm{~m}, 1 \mathrm{H}, 7-\mathrm{H}), 4.43\left(\mathrm{dd}, J_{1}=12.3 \mathrm{~Hz}, J_{2}=1.8 \mathrm{~Hz}\right.$, $\left.1 \mathrm{H}, 6-\mathrm{H}_{\mathrm{b}}\right) ; 4.12\left(\mathrm{~s}, 2 \mathrm{H}\right.$, oxazoline- $\left.\mathrm{CH}_{2}\right), 3.97(\mathrm{~m}, 1 \mathrm{H}, 8-\mathrm{H}), 3.62\left(\mathrm{dd}, J_{1}=13.2 \mathrm{~Hz}, J_{2}=9.9 \mathrm{~Hz}\right.$, $\left.1 \mathrm{H}, 8-\mathrm{CH}_{\mathrm{a}}\right), 3.33\left(\mathrm{dd}, J_{1}=13.2 \mathrm{~Hz}, J_{2}=9.9 \mathrm{~Hz}, 1 \mathrm{H}, 8-\mathrm{CH}_{\mathrm{b}}\right), 1.45\left(\mathrm{~s}, 6 \mathrm{H}, 2 \mathrm{CH}_{3}\right) . \mathrm{CIMS}: \mathrm{m} / \mathrm{z}(\%)$ $411\left(\mathrm{M}+\mathrm{H}^{+}, 90\right), 364\left(\mathrm{M}-\mathrm{NO}_{2}, 100\right)$. Anal. calcd. for $\mathrm{C}_{22} \mathrm{H}_{22} \mathrm{~N}_{2} \mathrm{O}_{6}: \mathrm{C}, 64.38 ; \mathrm{H}, 5.40 ; \mathrm{N}, 6.83$. Found: C, 64.46; H, 5.25; N, 6.71.

2-Amino-2-methylpropyl 2-(((7S*,8R*)-7-nitro-7,8-dihydro-6H-[1,3]dioxolo[4,5-g]chromen8-yl)methyl)benzoate (10). Oxazoline 9 (5.22 g) was dissolved in THF (70 $\mathrm{mL})$. Into this solution a $2 \mathrm{M}$ aqueous $\mathrm{HCl}$ solution $(70 \mathrm{~mL})$ was added, and the mixture was stirred at $60{ }^{\circ} \mathrm{C}$ overnight. The solution was then cooled and extracted twice with DCM $(70 \mathrm{~mL})$. The solvent was extracted twice with brine $(15 \mathrm{~mL})$, dried over $\mathrm{MgSO}_{4}$, filtered, and the solvents were removed under reduced pressure to yield amine hydrochloride 10 (5.36 g, 90.6\%); mp 125-130 ${ }^{\circ} \mathrm{C}$. ${ }^{1} \mathrm{H}$ NMR $\left(300 \mathrm{MHz}, \mathrm{CDCl}_{3}\right): \delta 8.08\left(\mathrm{dd}, J_{1}=1.2 \mathrm{~Hz}, J_{2}=7.8 \mathrm{~Hz}, 1 \mathrm{H}, \mathrm{ArH}\right), 7.51\left(\mathrm{td}, J_{1}=1.5\right.$ $\left.\mathrm{Hz}, J_{2}=7.5 \mathrm{~Hz}, 1 \mathrm{H}, \mathrm{ArH}\right), 7.38\left(\mathrm{td}, J_{1}=1.5 \mathrm{~Hz}, J_{2}=7.8 \mathrm{~Hz}, 1 \mathrm{H}, \mathrm{ArH}\right), 7.21\left(\mathrm{dd}, J_{1}=0.9 \mathrm{~Hz}, J_{2}\right.$ $=6.6 \mathrm{~Hz}, 1 \mathrm{H}, \mathrm{ArH}), 6.75(\mathrm{~s}, 1 \mathrm{H}, 4-\mathrm{H}), 6.39(\mathrm{~s}, 1 \mathrm{H}, 9-\mathrm{H}), 5.91,5.89\left(\mathrm{ABq}, J_{\mathrm{AB}}=1.5 \mathrm{~Hz}, 2 \mathrm{H}, 2-\right.$ $\left.\mathrm{H}_{2}\right), 4.84\left(\mathrm{dt}, J_{1}=12.3 \mathrm{~Hz}, J_{2}=2.4 \mathrm{~Hz}, 1 \mathrm{H}, 6-\mathrm{H}_{\mathrm{a}}\right), 4.64(\mathrm{~m}, 1 \mathrm{H}, 7-\mathrm{H}), 4.41\left(\mathrm{dd}, J_{1}=12.3 \mathrm{~Hz}, J_{2}\right.$ $\left.=2.1 \mathrm{~Hz}, 1 \mathrm{H}, 6-\mathrm{H}_{\mathrm{b}}\right), 4.12\left(\mathrm{~s}, 2 \mathrm{H}, \mathrm{COOCH}_{2}\right), 3.86(\mathrm{~m}, 1 \mathrm{H}, 8-\mathrm{H}), 3.62\left(\mathrm{dd}, J_{1}=13.5 \mathrm{~Hz}, J_{2}=4.8\right.$ $\left.\mathrm{Hz}, 1 \mathrm{H}, 8-\mathrm{CH}_{\mathrm{a}}\right), 3.33\left(\mathrm{dd}, J_{1}=13.2 \mathrm{~Hz}, J_{2}=10.5 \mathrm{~Hz}, 1 \mathrm{H}, 8-\mathrm{CH}_{\mathrm{b}}\right), 1.26\left(\mathrm{~s}, 6 \mathrm{H}, 2 \mathrm{CH}_{3}\right)$. ESIMS: $\mathrm{m} / \mathrm{z}(\%) 429\left(\mathrm{M}+\mathrm{H}^{+}, 100\right)$.

2-Amino-2-methylpropyl 2-(((7S*,8R*)-7-amino-7,8-dihydro-6H-[1,3]dioxolo[4,5-g]-chromen8-yl) methyl)benzoate (11). Ester 10 (5.36 g) was dissolved in acetic acid (150 mL), and powdered zinc $(3.0 \mathrm{~g})$ was added. The mixture was stirred vigorously at $60^{\circ} \mathrm{C}$ for $6 \mathrm{~h}$, at which time the reaction was filtered through Celite, and the filtered solids were rinsed with acetic acid. Water $(300 \mathrm{~mL})$ was added to the filtrate, and the solution was washed once with DCM. The aqueous solution was then basified with ammonia and extracted with DCM (3 x $40 \mathrm{~mL})$. The organic solvent was then washed twice with brine, dried over $\mathrm{MgSO}_{4}$, filtered, and the solvents removed under reduced pressure. The residue was then recrystallized in two crops from hexanes/EtOAc to yield amine 11 (4.11 g, 85.5\%); mp $137{ }^{\circ} \mathrm{C} .{ }^{1} \mathrm{H}$ NMR (300 $\left.\mathrm{MHz}, \mathrm{CDCl}_{3}\right): \delta$ $8.01\left(\mathrm{dd}, J_{1}=1.5 \mathrm{~Hz}, J_{2}=7.5 \mathrm{~Hz}, 1 \mathrm{H}, \mathrm{ArH}\right), 7.47\left(\mathrm{dt}, J_{1}=1.5 \mathrm{~Hz}, J_{2}=7.5 \mathrm{~Hz}, 1 \mathrm{H}, \mathrm{ArH}\right), 7.34$ $\left(\mathrm{dt}, J_{1}=1.2 \mathrm{~Hz}, J_{2}=7.5 \mathrm{~Hz}, 1 \mathrm{H}, \mathrm{ArH}\right), 7.16\left(\mathrm{dd}, J_{1}=1.2 \mathrm{~Hz}, J_{2}=6.6 \mathrm{~Hz}, 1 \mathrm{H}, \mathrm{ArH}\right), 6.56(\mathrm{~s}, 1 \mathrm{H}$, $4-\mathrm{H}), 6.41(\mathrm{~s}, 1 \mathrm{H}, 9-\mathrm{H}), 5.88,5.86\left(\mathrm{ABq}, J_{\mathrm{AB}}=1.5 \mathrm{~Hz}, 2 \mathrm{H}, 2-\mathrm{H}_{2}\right), 4.25\left(\mathrm{dd}, J_{1}=11.1 \mathrm{~Hz}, J_{2}=\right.$ 
$\left.1.5 \mathrm{~Hz}, 1 \mathrm{H}, 6-\mathrm{H}_{\mathrm{a}}\right), 4.09\left(\mathrm{~s}, 2 \mathrm{H}, \mathrm{COOCH}_{2}\right), 4.01\left(\mathrm{dt}, J_{1}=1.8 \mathrm{~Hz}, J_{2}=11.1 \mathrm{~Hz}, 1 \mathrm{H}, 6-\mathrm{H}_{\mathrm{b}}\right), 3.53$ $\left(\mathrm{dd}, J_{1}=13.2 \mathrm{~Hz}, J_{2}=5.7 \mathrm{~Hz}, 1 \mathrm{H}, 8-\mathrm{CH}_{\mathrm{a}}\right), 3.06-2.99\left(\mathrm{~m}, 2 \mathrm{H}, 8-\mathrm{CH}_{\mathrm{b}}, 7-\mathrm{H}\right), 2.82(\mathrm{~m}, 1 \mathrm{H}, 8-\mathrm{H})$, 1.55 (br, 4H, 2NH$), 1.17\left(\mathrm{~s}, 6 \mathrm{H}, 2 \mathrm{CH}_{3}\right)$. ESIMS: m/z (\%) $399\left(\mathrm{M}+\mathrm{H}^{+}, 100\right)$. Anal. calcd. for $\mathrm{C}_{22} \mathrm{H}_{26} \mathrm{~N}_{2} \mathrm{O}_{5}$ : C, 66.32; H, 6.58; N, 6.66. Found: C, 66.02; H, 6.78; N, 6.66.

$\left(6 \mathrm{a} S^{*}, 13 \mathrm{a} R^{*}\right)-6 \mathrm{a}, 7,13,13 a-T e t r a h y d r o[1,3]$ dioxolo[4',5':6,7]chromeno[3,4-b]benzo[e]azepin8(6H)-one (12). Amine 11 (4.25 g) was dissolved in EtOAc (30 mL), and ethylene glycol (30 $\mathrm{mL}$ ) was added. EtOAc was then removed under reduced pressure. The resulting ethylene glycol solution was transferred to an Erlenmeyer flask, placed into a commercial microwave oven and heated at the high setting for $2 \mathrm{~min}$, then left to stand for 1 minute. This sequential heating/cooling procedure was repeated 3 times, and the solution was placed in an ice bath and cooled to $0{ }^{\circ} \mathrm{C}$. The product crystallized, a small amount of cold $\mathrm{EtOH}$ was added, the mixture was filtered, and the crystals were rinsed on the filter with cold $\mathrm{EtOH}$ and dried to yield pure lactam 12 (1.63 g, 49\%) as small white crystals; mp: >300 ${ }^{\circ} \mathrm{C}$. ${ }^{1} \mathrm{H}-\mathrm{NMR}\left(300 \mathrm{MHz}, \mathrm{DMSO}-d_{6}\right)$ : $\delta 8.44(\mathrm{~d}, J=6.0 \mathrm{~Hz}, 1 \mathrm{H}, \mathrm{ArH}), 7.52(\mathrm{~d}, J=7.8 \mathrm{~Hz}, 1 \mathrm{H}, \mathrm{ArH}), 7.39-7.28(\mathrm{~m}, 3 \mathrm{H}, 2 \mathrm{ArH}, \mathrm{NH})$, $7.23(\mathrm{~s}, 1 \mathrm{H}, 4-\mathrm{H}), 6.37(\mathrm{~s}, 1 \mathrm{H}, 14-\mathrm{H}), 5.92\left(\mathrm{~d}, J=9.6 \mathrm{~Hz}, 2 \mathrm{H}, 2-\mathrm{H}_{2}\right), 4.25\left(\mathrm{dd}, J_{1}=9.9 \mathrm{~Hz}, J_{2}=\right.$ $\left.4.5 \mathrm{~Hz}, 1 \mathrm{H}, 6-\mathrm{H}_{\mathrm{a}}\right), 4.11\left(\mathrm{t}, J=9.9 \mathrm{~Hz}, 1 \mathrm{H}, 6-\mathrm{H}_{\mathrm{b}}\right), 3.41\left(\mathrm{~d}, J=14.4 \mathrm{~Hz}, 1 \mathrm{H}, 13-\mathrm{H}_{\mathrm{a}}\right), 3.31-3.27(\mathrm{~m}$, $1 \mathrm{H}, 6 \mathrm{a}-\mathrm{H}), 3.16\left(\mathrm{dd}, J_{1}=14.4 \mathrm{~Hz}, J_{2}=8.4 \mathrm{~Hz}, 1 \mathrm{H}, 13-\mathrm{H}_{\mathrm{b}}\right), 3.09-3.02(\mathrm{~m}, 1 \mathrm{H}, 13 \mathrm{a}-\mathrm{H})$. EIMS: $\mathrm{m} / \mathrm{z}(\%) 310\left(\mathrm{M}+\mathrm{H}^{+}, 100\right)$.

\section{$\left(6 a S^{*}, 13 a R^{*}\right)-6,6 a, 7,8,13,13 a-H e x a h y d r o[1,3]$ dioxolo[4',5':6,7]chromeno[3,4-b]benzo[e]}

azepine (13). Lactam $12(1.63 \mathrm{~g}, 5.27 \mathrm{mmol})$ was suspended in dry THF (40 mL) and a $1 \mathrm{M}$ solution of $\mathrm{BH}_{3}$ in THF $(26.3 \mathrm{~mL}, 26.35 \mathrm{mmol})$ was added. This reaction was stirred at reflux for $48 \mathrm{~h}$, then cooled and quenched with excess water. The solution was extracted with DCM, the extract was washed once with brine, dried over $\mathrm{MgSO}_{4}$, filtered, and the solvent was removed under reduced pressure. The residue was then stirred overnight with a $2 \mathrm{M}$ ethanolic $\mathrm{HCl}$ solution $(20 \mathrm{~mL})$. Aqueous ammonia was then added to basify the solution, water was added, and the free base was extracted into DCM $(30 \mathrm{~mL})$. This solution was washed with water, dried over $\mathrm{MgSO}_{4}$, filtered, and the solvents removed under reduced pressure. The crude residue was then crystallized from EtOH to yield 13 (1.31 g, 84\%); mp 105-106 ${ }^{\circ} \mathrm{C}$. ${ }^{1} \mathrm{H}$ NMR $\left(300 \mathrm{MHz}, \mathrm{CDCl}_{3}\right)$ : $\delta 7.32(\mathrm{~d}, J=6.9 \mathrm{~Hz}, 1 \mathrm{H}, \mathrm{ArH}), 7.24-7.15$ (m, 3H, 3ArH), 6.89 (s, 1H, 4-H), 6.36 (s, 1H, 14-H), $5.88\left(\mathrm{~d}, J=2.1 \mathrm{~Hz}, 2 \mathrm{H}, 2-\mathrm{H}_{2}\right), 4.17-4.12\left(\mathrm{~m}, 2 \mathrm{H}, 6-\mathrm{H}_{\mathrm{a}}, 8-\mathrm{H}_{\mathrm{a}}\right), 4.00\left(\mathrm{~d}, J=14.7 \mathrm{~Hz}, 1 \mathrm{H}, 8-\mathrm{H}_{\mathrm{b}}\right)$, $3.64\left(\mathrm{t}, J=10.2 \mathrm{~Hz}, 1 \mathrm{H}, 6-\mathrm{H}_{\mathrm{b}}\right), 3.29(\mathrm{br} \mathrm{d}, J=14.6 \mathrm{~Hz}, 1 \mathrm{H}, 13 \mathrm{a}-\mathrm{H}), 3.22\left(\mathrm{dt}, J_{1}=10.5 \mathrm{~Hz}, J_{2}=\right.$ $3.6 \mathrm{~Hz}, 1 \mathrm{H}, 6 \mathrm{a}-\mathrm{H}), 3.09\left(\mathrm{dd}, J_{1}=14.4 \mathrm{~Hz}, J_{2}=10.5 \mathrm{~Hz}, 1 \mathrm{H}, 13-\mathrm{H}_{\mathrm{a}}\right), 2.63(\mathrm{br} \mathrm{t}, J=9.9 \mathrm{~Hz}, 1 \mathrm{H}$, 13-H $\mathrm{H}_{\mathrm{b}}$. EIMS: m/z (\%) $295\left(\mathrm{M}+\mathrm{H}^{+}, 100\right)$. Anal. calcd. for $\mathrm{C}_{18} \mathrm{H}_{17} \mathrm{NO}_{3}: \mathrm{C}, 73.20 ; \mathrm{H}, 5.80 ; \mathrm{N}$, 4.74. Found: C, 73.53; H, 6.02; N, 4.83.

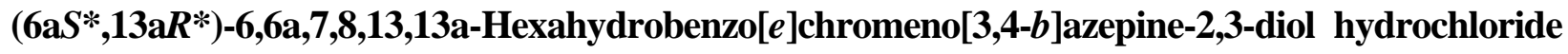
(5). Amine 13 (268 mg, $0.907 \mathrm{mmol})$ was dissolved in DCM (10 mL) and cooled to $-78^{\circ} \mathrm{C}$. Into this flask, a $1 \mathrm{M} \mathrm{BCl}_{3}$ solution in DCM $(3.6 \mathrm{~mL}, 3.6 \mathrm{mmol})$ was added dropwise. This solution was then warmed to room temperature and stirred overnight. The reaction mixture was then cooled to $0{ }^{\circ} \mathrm{C}$ and dry methanol $(5 \mathrm{~mL})$ was added dropwise. The solvents were then removed under reduced pressure, and dry methanol $(5 \mathrm{~mL})$ was once again added. The solvents were 
removed, and the process was repeated one more time. The residue was then recrystallized from $\mathrm{EtOH} / \mathrm{EtOAc}$ and dried under vacuum to afford the hydrochloride salt 5 (183 $\mathrm{mg}, 63 \%) ; \mathrm{mp}>$ $300{ }^{\circ} \mathrm{C}$ dec. ${ }^{1} \mathrm{H}$ NMR $\left(300 \mathrm{MHz}, \mathrm{D}_{2} \mathrm{O}\right): \delta 7.51(\mathrm{~d}, J=18.3 \mathrm{~Hz}, 1 \mathrm{H}, \mathrm{ArH}), 7.44-7.31(\mathrm{~m}, 3 \mathrm{H}$, $3 \mathrm{ArH}), 7.08$ (s, 1H, 4-H), 6.43 (s, 1H, 1-H), 4.59,4.48 (ABq, J = $\left.14.4 \mathrm{~Hz}, 2 \mathrm{H}, 8-\mathrm{H}_{2}\right), 4.38$ (dd, $J_{1}$ $\left.=9 \mathrm{~Hz}, J_{2}=1.8 \mathrm{~Hz}, 1 \mathrm{H}, 6-\mathrm{H}_{\mathrm{a}}\right), 3.88\left(\mathrm{q}, J=10.8 \mathrm{~Hz}, 1 \mathrm{H}, 6-\mathrm{H}_{\mathrm{b}}\right), 3.86-3.78(\mathrm{~m}, 1 \mathrm{H}, 6 \mathrm{a}-\mathrm{H}), 3.51-$ $3.43(\mathrm{~m}, 1 \mathrm{H}, 13 \mathrm{a}-\mathrm{H}), 3.16-3.06\left(\mathrm{~m}, 2 \mathrm{H}, 13-\mathrm{H}_{2}\right)$. EIMS: $\mathrm{m} / \mathrm{z}(\%) 284\left(\mathrm{M}+\mathrm{H}^{+}, 100\right)$. Anal. calcd. for $\mathrm{C}_{17} \mathrm{H}_{18} \mathrm{ClNO}_{3}$ : C, 63.85; H, 5.67; N, 4.38. Found: C, 63.50; H, 5.83; N, 4.16. (7S*,8R*)-8-(2-((1,3-Dioxolan-2-yl)methyl)phenyl)-7-nitro-7,8-dihydro-6H-[1,3]dioxolo[4,5-g] chromene (15). Dioxolane $14^{24}(5.0 \mathrm{~g}, 20.8 \mathrm{mmol})$ was dissolved in dry THF $(100 \mathrm{~mL})$ and cooled to $-78{ }^{\circ} \mathrm{C}$. Into this flask, a $2.5 \mathrm{M}$ solution of $n$-BuLi in hexane $(8.4 \mathrm{~mL}, 20.8 \mathrm{mmol})$ of was introduced. After stirring at $-78{ }^{\circ} \mathrm{C}$ for $1 \mathrm{~h}$, the lithium reagent was cannulated into the flask containing nitrochromene $8(2.0 \mathrm{~g}, 9.04 \mathrm{mmol})$ in dry THF $(150 \mathrm{~mL})$ at $-78{ }^{\circ} \mathrm{C}$. This mixture was stirred for $2 \mathrm{~h}$, quenched with dilute acetic acid, and then warmed to room temperature. Water was added, and the mixture was extracted several times with DCM. The pooled extracts were washed once with brine $(50 \mathrm{~mL})$, dried over $\mathrm{MgSO}_{4}$, filtered, and the solvents removed under reduced pressure to yield the desired product as a dark oil. Silica gel flash column chromatography eluting with hexanes/EtOAc 4:1 provided $15(1.08 \mathrm{~g}, 33.3 \%)$ as an oil that crystallized on standing, and which could be easily recrystallized from $\mathrm{MeOH} ; \mathrm{mp} 134-136{ }^{\circ} \mathrm{C}$. ${ }^{1} \mathrm{H}$ NMR $\left(300 \mathrm{MHz}, \mathrm{CDCl}_{3}\right): \delta 7.19-7.16(\mathrm{~m}, 3 \mathrm{H}, 3 \mathrm{ArH}), 6.90\left(\mathrm{dd}, J_{1}=1.5 \mathrm{~Hz}, J_{2}=7.5 \mathrm{~Hz}, 1 \mathrm{H}\right.$, $\mathrm{ArH}), 6.44(\mathrm{~s}, 1 \mathrm{H}, 4-\mathrm{H}), 6.30(\mathrm{~s}, 1 \mathrm{H}, 9-\mathrm{H}), 5.86\left(\mathrm{ABq}, J_{\mathrm{AB}}=1.2 \mathrm{~Hz}, 2 \mathrm{H}, 2-\mathrm{H}_{2}\right), 5.29$ (br s, $1 \mathrm{H}, 6-$ $\left.\mathrm{H}_{\mathrm{a}}\right), 5.109\left(\mathrm{t}, J=4.5 \mathrm{~Hz}, 1 \mathrm{H}, \mathrm{CH}\right.$-dioxolane), 4.88-4.92 (m, 1H, 6- $\left.\mathrm{H}_{\mathrm{b}}\right), 4.69$ (ddd, $J_{\text {trans }}=12.3$ $\left.\mathrm{Hz}, J_{1}=3.6 \mathrm{~Hz}, J_{2}=1.5 \mathrm{~Hz}, 1 \mathrm{H}, 7-\mathrm{H}\right), 4.28\left(\mathrm{dd}, J_{\text {trans }}=12.3 \mathrm{~Hz}, J_{1}=2.1 \mathrm{~Hz}, 1 \mathrm{H}, 8-\mathrm{H}\right), 3.92-$ $3.84\left(\mathrm{~m}, 4 \mathrm{H}, \mathrm{OCH}_{2} \mathrm{CH}_{2} \mathrm{O}\right), 3.21\left(\mathrm{dd}, J_{1}=14.7 \mathrm{~Hz}, J_{2}=4.2 \mathrm{~Hz}, 1 \mathrm{H}, \mathrm{ArCH}_{\mathrm{a}}\right), 3.09$ (dd, $J_{1}=15$ $\left.\mathrm{Hz}, J_{2}=5.1 \mathrm{~Hz}, 1 \mathrm{H}, \mathrm{ArCH}_{\mathrm{b}}\right)$. ESIMS: $\mathrm{m} / \mathrm{z}(\%) 408\left(\mathrm{M}+\mathrm{Na}^{+}, 100\right)$. Anal. calcd. for $\mathrm{C}_{20} \mathrm{H}_{19} \mathrm{NO}_{7}$ : C, 62.33; H, 4.97; N, 3.63. Found: C, 62.28; H, 5.00; N, 3.63 .

\section{2-(2-((7S*,8R*)-7-Nitro-7,8-dihydro-6H-[1,3]dioxolo[4,5-g]chromen-8-yl)phenyl)acetic acid} (16). Dioxolane $15(100 \mathrm{mg}, 0.259 \mathrm{mmol})$ was dissolved in THF $(1 \mathrm{~mL})$. Into this solution acetic acid $(10 \mathrm{~mL})$ followed by $2 \mathrm{M}$ aqueous $\mathrm{HCl}$ solution $(3 \mathrm{~mL})$ were added, and the reaction was heated at reflux for $3 \mathrm{~h}$. The reaction was cooled to room temperature, quenched with water, and extracted twice with DCM $(20 \mathrm{~mL})$. The extract was washed twice with brine $(15 \mathrm{~mL})$, dried over $\mathrm{MgSO}_{4}$, filtered, and the solvents removed under reduced pressure to provide the crude aldehyde, which was used without further purification. This aldehyde was dissolved in THF (15 $\mathrm{mL})$, and $30 \% \mathrm{H}_{2} \mathrm{O}_{2}(0.5 \mathrm{~mL})$ and $\mathrm{KH}_{2} \mathrm{PO}_{4}(11 \mathrm{mg}, 0.778 \mathrm{mmol})$ were added. After stirring for 5 min, $\mathrm{NaClO}_{4}(47 \mathrm{mg}, 0.52 \mathrm{mmol})$ dissolved in a minimal amount of water was added dropwise to the mixture. The reaction was stirred overnight, then diluted with $1 \mathrm{M} \mathrm{HCl}(15 \mathrm{~mL})$ and extracted twice with DCM $(20 \mathrm{~mL})$. The solvent was dried over $\mathrm{MgSO}_{4}$, filtered, and the solvents removed under reduced pressure to give a yellow oil. Acid/base extraction of the crude oil with $\mathrm{NaHCO}_{3}$ solution and $1 \mathrm{M}$ aqueous $\mathrm{HCl}$ yielded nitroacetic acid 16 (50 mg, 53.8\%); mp 167-172 ${ }^{\circ} \mathrm{C} .{ }^{1} \mathrm{H}$ NMR $\left(300 \mathrm{MHz}, \mathrm{CDCl}_{3}\right): \delta 7.28-7.17$ (m, 3H, 3ArH), 7.00-6.97 (m, 1H, ArH), $6.45(\mathrm{~s}, 1 \mathrm{H}, 4-\mathrm{H}), 6.26(\mathrm{~s}, 1 \mathrm{H}, 9-\mathrm{H}), 5.89,5.87\left(\mathrm{ABq}, J_{\mathrm{AB}}=1.5 \mathrm{~Hz}, 2 \mathrm{H}, 2-\mathrm{H}_{2}\right), 5.11(\mathrm{~d}, J=3.3$ 
$\left.\mathrm{Hz}, 1 \mathrm{H}, 6-\mathrm{H}_{\mathrm{a}}\right), 4.87-4.83\left(\mathrm{~m}, 1 \mathrm{H}, 6-\mathrm{H}_{\mathrm{b}}\right), 4.67\left(\mathrm{ddd}, J_{\text {trans }}=11.1 \mathrm{~Hz}, J_{1}=3.6 \mathrm{~Hz}, J_{2}=0.9 \mathrm{~Hz}, 1 \mathrm{H}\right.$, $7-\mathrm{H}), 4.35\left(\mathrm{dd}, J_{\text {trans }}=12.0 \mathrm{~Hz}, J_{1}=2.4 \mathrm{~Hz}, 1 \mathrm{H}, 8-\mathrm{H}\right), 3.90,3.86\left(\mathrm{ABq}, J_{A B}=16 \mathrm{~Hz}, 2 \mathrm{H}\right.$, $\left.\mathrm{CH}_{2} \mathrm{COOH}\right)$. CIMS: $\mathrm{m} / \mathrm{z}(\%) 358\left(\mathrm{M}+\mathrm{H}^{+}, 12\right), 310\left(\mathrm{M}+\mathrm{H}-\mathrm{HNO}_{2}, 100\right)$. Anal. calcd. for $\mathrm{C}_{18} \mathrm{H}_{15} \mathrm{NO}_{7}$ : C, 60.50; H, 4.23; N, 3.92. Found: C, 60.40; H, 4.45; N, 3.83.

Methyl 2-(2-((7S*,8R*)-7-nitro-7,8-dihydro-6H-[1,3]dioxolo[4,5-g]chromen-8-yl)phenyl)acetate (17). Acid 16 (1.0 g, $2.83 \mathrm{mmol})$ was dissolved in DCM (50 mL). To this solution MeOH $(0.13$ $\mathrm{mL}, 3.11 \mathrm{mmol}$ ), DCC (642 mg, $3.11 \mathrm{mmol}$ ), and DMAP (34 mg, $0.28 \mathrm{mmol}$ ) were added. After stirring for $5 \mathrm{~h}$, the solvent was removed and ether was added to the residual paste. The mixture was filtered and the filtered solid was washed on the filter with ether. The filtrate was dried over $\mathrm{MgSO}_{4}$, filtered, and the solvents were removed under reduced pressure to provide a dark oil. Silica gel flash column chromatography, eluting with hexanes/EtOAc 3:1, afforded 17 (0.51 g, 52.5\%); mp 110-114 ${ }^{\circ} \mathrm{C} .{ }^{1} \mathrm{H}$ NMR (300 MHz, $\left.\mathrm{CDCl}_{3}\right): \delta 7.21-7.12$ (m, 3H, 3ArH), 6.91-6.88 $(\mathrm{m}, 1 \mathrm{H}, \mathrm{ArH}), 6.36(\mathrm{~s}, 1 \mathrm{H}, 4-\mathrm{H}), 6.19(\mathrm{~s}, 1 \mathrm{H}, 9-\mathrm{H}), 5.77$ (d, $\left.J=3.0 \mathrm{~Hz}, 2 \mathrm{H}, 2-\mathrm{H}_{2}\right), 5.04(\mathrm{~d}, J=$ $\left.3.3 \mathrm{~Hz}, 1 \mathrm{H}, 6-\mathrm{H}_{\mathrm{a}}\right), 4.80-4.77\left(\mathrm{~m}, 1 \mathrm{H}, 6-\mathrm{H}_{\mathrm{b}}\right), 4.58\left(\mathrm{dd}, J_{\text {trans }}=12.0 \mathrm{~Hz}, J_{1}=4.2 \mathrm{~Hz}, 1 \mathrm{H}, 7-\mathrm{H}\right)$, $4.25\left(\mathrm{dd}, J_{\text {trans }}=12.0 \mathrm{~Hz}, J_{1}=2.1 \mathrm{~Hz}, 1 \mathrm{H}, 8-\mathrm{H}\right), 3.76\left(\mathrm{~s}, 2 \mathrm{H}, \mathrm{CH}_{2} \mathrm{COOMe}\right), 3.61(\mathrm{~s}, 3 \mathrm{H}$, $\left.\mathrm{COOCH}_{3}\right)$. ESIMS: $m / z(\%) 372\left(\mathrm{M}+\mathrm{H}^{+}, 100\right)$.

Methyl 2-(2-((7S*,8R*)-7-amino-7,8-dihydro-6H-[1,3]dioxolo[4,5-g]chromen-8-yl)phenyl)acetate (18). Ester 17 (300 mg, $0.808 \mathrm{mmol})$ was dissolved in acetic acid (25 mL) and powdered zinc $(528 \mathrm{mg}$ ) was added. The mixture was stirred vigorously at room temperature overnight, then was filtered through Celite, and the filtered solids were rinsed on the filter with acetic acid. Water $(300 \mathrm{~mL})$ was added to the filtrate, and the solution was washed once with DCM. The aqueous mixture was then basified with ammonia and extracted with DCM (3 x $40 \mathrm{~mL})$. The organic extract was washed twice with brine, dried over $\mathrm{MgSO}_{4}$, filtered, and the solvents were removed under reduced pressure to give a light brown oil. Acid/base extraction of the crude oil with $1 \mathrm{M} \mathrm{HCl}$ solution and $1 \mathrm{M} \mathrm{NaOH}$ solution yielded amine 18 (260 mg, 94.3\%) as a gummy solid. ${ }^{1} \mathrm{H}$ NMR $\left(300 \mathrm{MHz}, \mathrm{CDCl}_{3}\right): \delta 7.25-7.09(\mathrm{~m}, 3 \mathrm{H}, 3 \mathrm{ArH}), 6.91-6.88(\mathrm{~m}, 1 \mathrm{H}, \mathrm{ArH}), 6.35$ $(\mathrm{s}, 1 \mathrm{H}, 4-\mathrm{H}), 6.07(\mathrm{~s}, 1 \mathrm{H}, 9-\mathrm{H}), 5.77,5.76\left(\mathrm{ABq}, J_{\mathrm{AB}}=1.2 \mathrm{~Hz}, 2 \mathrm{H}, 2-\mathrm{H}_{2}\right), 4.09$ (dd, $J_{\text {trans }}=11.1$ $\left.\mathrm{Hz}, J_{1}=2.4 \mathrm{~Hz}, 1 \mathrm{H}, 8-\mathrm{H}\right), 3.99\left(\mathrm{~d}, J=3.3 \mathrm{~Hz}, 1 \mathrm{H}, 6-\mathrm{H}_{\mathrm{a}}\right), 3.83-3.75\left(\mathrm{~m}, 2 \mathrm{H}, 6-\mathrm{H}_{\mathrm{b}}, 7-\mathrm{H}\right), 3.69$ (s, $\left.2 \mathrm{H}, \mathrm{CH}_{2} \mathrm{CO}_{2}\right), 3.63$ (s, 3H, $\left.\mathrm{CO}_{2} \mathrm{CH}_{3}\right)$. CIMS: m/z (\%) $342\left(\mathrm{M}+\mathrm{H}^{+}, 100\right), 325\left(\mathrm{M}+\mathrm{H}-\mathrm{NH}_{3}, 33\right)$.

$\left(7 \mathrm{a} S^{*}, 14 \mathrm{~b} R^{*}\right)-7,7 \mathrm{a}, 8,14 \mathrm{~b}-T e t r a h y d r o-[1,3]$ dioxolo[4',5':6,7]chromeno[3,4-b]benzo[d]azepin6(5H)-one (19). Amine 18 (200 mg, $0.586 \mathrm{mmol})$ was dissolved in dry $\mathrm{MeOH}(25 \mathrm{~mL}), \mathrm{NaOMe}$ in $\mathrm{MeOH}(25 \% \mathrm{wt}, 0.14 \mathrm{~mL})$ was introduced into the solution, and the mixture was heated at reflux overnight. The reaction was then concentrated under reduced pressure. The resulting crude oil was dissolved in DCM, the organic solution washed with water, dried over $\mathrm{MgSO}_{4}$, filtered, and the solvent removed under reduced pressure. The crude residue was crystallized from $\mathrm{MeOH}$ to afford lactam 19 (100 mg, 55\%); mp: > $240{ }^{\circ} \mathrm{C}$ dec. ${ }^{1} \mathrm{H}$ NMR (300 $\left.\mathrm{MHz}, \mathrm{CDCl}_{3}\right): \delta 7.19-7.17$ (m, 3H, 3ArH), 7.00-6.97 (m, 1H, ArH), 6.49 (s, 1H, 5-H), $6.42(\mathrm{~s}, 1 \mathrm{H}, 1-\mathrm{H}), 5.91,5.86(\mathrm{ABq}$, $\left.J_{\mathrm{AB}}=1.2 \mathrm{~Hz}, 2 \mathrm{H}, 3-\mathrm{H}_{2}\right), 5.46(\mathrm{br} \mathrm{s}, 1 \mathrm{H}, \mathrm{NH}), 4.68\left(\mathrm{~d}, J_{\text {trans }}=10.8 \mathrm{~Hz}, 1 \mathrm{H}, 14 \mathrm{~b}-\mathrm{H}\right), 4.24(\mathrm{~d}, J=$ $\left.16.5 \mathrm{~Hz}, 1 \mathrm{H}, 10-\mathrm{H}_{\mathrm{a}}\right), 3.98\left(\mathrm{dd}, J_{1}=9.9 \mathrm{~Hz}, J_{2}=3.6 \mathrm{~Hz}, 1 \mathrm{H}, 7-\mathrm{H}_{\mathrm{a}}\right), 3.77(\mathrm{t}, J=10.8 \mathrm{~Hz}, 1 \mathrm{H}, 7 \mathrm{a}-$ 
H), 3.63-3.56 (m, 2H, 7- $\left.\mathrm{H}_{\mathrm{b}}, 10-\mathrm{H}_{\mathrm{b}}\right)$. ESIMS: m/z (\%) $310\left(\mathrm{M}+\mathrm{H}^{+}, 100\right)$. Anal. calcd. for $\mathrm{C}_{18} \mathrm{H}_{15} \mathrm{NO}_{4} \cdot 0.22 \mathrm{H}_{2} \mathrm{O}: \mathrm{C}, 69.01 ; \mathrm{H}, 4.97 ; \mathrm{N}, 4.47$. Found: C, 69.02; H, 5.17; N, 4.36.

(7aS*,14bR*)-5,6,7,7a,8,14b-Hexahydro[1,3]dioxolo[4',5':6,7]chromeno[3,4-b]benzo[d]azepine (20). Lactam 19 (40 mg, $0.129 \mathrm{mmol})$ was suspended in dry THF (10 mL) and a $1 \mathrm{M}$ solution of $\mathrm{BH}_{3}(0.8 \mathrm{~mL}, 0.8 \mathrm{mmol})$ in THF was added. This solution was stirred at reflux for $24 \mathrm{~h}$, then cooled and quenched with excess water. The solution was extracted twice with DCM (20 mL). The organic extract was washed once with brine, dried over $\mathrm{MgSO}_{4}$, filtered, and the solvent was removed under reduced pressure. The residue was then stirred for six hours with $6 \mathrm{M}$ ethanolic $\mathrm{HCl}$ solution $(10 \mathrm{~mL})$. The solvent was removed, $\mathrm{MeOH}$ was added and removed under vacuum 3 times. Acid/base extraction of the crude product yielded amine 20 (20 mg, 52.4\%). ${ }^{1} \mathrm{H}$ NMR $\left(300 \mathrm{MHz}, \mathrm{CDCl}_{3}\right): \delta 7.18-6.98(\mathrm{~m}, 3 \mathrm{H}, 3 \mathrm{ArH}), 6.70(\mathrm{~d}, J=13.2 \mathrm{~Hz}, 1 \mathrm{H}, \mathrm{ArH}), 6.43(\mathrm{~s}, 1 \mathrm{H}, 5-$ $\mathrm{H}), 6.39(\mathrm{~s}, 1 \mathrm{H}, 1-\mathrm{H}), 5.89,5.84\left(\mathrm{ABq}, J_{\mathrm{AB}}=1.2 \mathrm{~Hz}, 2 \mathrm{H}, 3-\mathrm{H}_{2}\right), 4.41\left(\mathrm{~d}, J_{\text {trans }}=8.1 \mathrm{~Hz}, 1 \mathrm{H}, 14 \mathrm{~b}-\right.$ H), $4.11\left(\mathrm{dd}, J_{1}=10.5 \mathrm{~Hz}, J_{2}=4.8 \mathrm{~Hz}, 1 \mathrm{H}, 7-\mathrm{H}_{\mathrm{a}}\right) 3.54(\mathrm{t}, J=11.1 \mathrm{~Hz}, 1 \mathrm{H}, 7 \mathrm{a}-\mathrm{H}), 3.39-3.26(\mathrm{~m}$, $\left.2 \mathrm{H}, 7-\mathrm{H}_{\mathrm{b}}, 9-\mathrm{H}_{\mathrm{a}}\right), 2.97-2.89\left(\mathrm{~m}, 1 \mathrm{H}, 9-\mathrm{H}_{\mathrm{b}}\right), 2.81-2.75\left(\mathrm{~m}, 2 \mathrm{H}, 10-\mathrm{H}_{2}\right)$. ESIMS: m/z (\%) 296 $\left(\mathrm{M}+\mathrm{H}^{+}, 100\right)$.

$\left(6 \mathrm{a} S^{*}, 13 \mathrm{~b} R^{*}\right)-6,6 \mathrm{a}, 7,8,9,13 \mathrm{~b}-H e x a h y d r o b e n z o[d]$ chromeno[3,4-b]azepine-2,3-diol hydrochloride (6). Amine 20 (40 mg, $0.135 \mathrm{mmol})$ was dissolved in DCM $(10 \mathrm{~mL})$ and cooled to $-78{ }^{\circ} \mathrm{C}$. Into this flask, a $1 \mathrm{M} \mathrm{BCl}_{3}$ solution in DCM $(0.54 \mathrm{~mL} 0.54 \mathrm{mmol})$ was added dropwise. This solution was then warmed to room temperature and stirred for $5 \mathrm{~h}$. The reaction was concentrated under reduced pressure, the residue was recrystallized from ethanol/ether and dried under vacuum to provide the hydrochloride salt 6 (30 mg, 69.8\%); mp $>300{ }^{\circ} \mathrm{C} \mathrm{dec}$. ${ }^{1} \mathrm{H}$ NMR $(300 \mathrm{MHz}$, DMSO$d_{6}$ ): $\delta 9.88$ (br s, $1 \mathrm{H}, \mathrm{NH}_{2}{ }^{+}$), 9.35 (br s, $1 \mathrm{H}, \mathrm{NH}_{2}{ }^{+}$), 9.16 (s, 1H, OH), 8.69 (s, 1H, OH), 7.24-7.12 (m, 3H, 3ArH), $6.63(\mathrm{~d}, J=4.5 \mathrm{~Hz}, 1 \mathrm{H}, \mathrm{ArH}), 6.35(\mathrm{~s}, 1 \mathrm{H}, 4-\mathrm{H}), 6.30(\mathrm{~s}, 1 \mathrm{H}, 1-\mathrm{H}), 4.79\left(\mathrm{~d}, J_{\text {trans }}\right.$ $=8.5 \mathrm{~Hz}, 1 \mathrm{H}, 13 \mathrm{~b}-\mathrm{H}), 4.27\left(\mathrm{dd}, J_{1}=10.5 \mathrm{~Hz}, J_{2}=4.5 \mathrm{~Hz}, 1 \mathrm{H}, 6-\mathrm{H}_{\mathrm{a}}\right) 3.68(\mathrm{t}, J=11.0 \mathrm{~Hz}, 1 \mathrm{H}$, 6a-H), 3.60-3.50 (m, 2H, 6- $\left.\mathrm{H}_{\mathrm{b}}, 8-\mathrm{H}_{\mathrm{a}}\right), 2.97-2.94\left(\mathrm{~m}, 3 \mathrm{H}, 8-\mathrm{H}_{\mathrm{b}}, 9-\mathrm{H}_{2}\right)$. ESIMS: m/z (\%) 284 $\left(\mathrm{M}+\mathrm{H}^{+}, 100\right)$.

Molecular modeling. Compounds were modeling using Spartan ES 3.0.0 (Wavefunction Inc, Irvine, CA.). Geometry optimization was carried out on the protonated molecules in a vacuum, using the semi-empirical AM-1 force fields. Different starting conformations were manually built, followed by minimization, and the lowest energy structures were used for comparison.

\section{Pharmacology}

Materials. Chlorpromazine, SCH-23390, (+)-butaclamol, and ketanserin were purchased from Sigma-Aldrich Chemical Company (St. Louis, MO). $\left[{ }^{3} \mathrm{H}\right] \mathrm{SCH}-23390(73.1 \mathrm{Ci} / \mathrm{mmol})$ and $\left[{ }^{3} \mathrm{H}\right]$ Spiperone $(75 \mathrm{Ci} / \mathrm{mmol})$ were purchased from PerkinElmer Life Sciences (Massachusetts, United States). Porcine brain tissue was donated by Purdue Butcher Block and striatal tissue was dissected and prepared as previously described. ${ }^{22}$ 


\section{Competition binding experiments}

For competition binding experiments, all drug dilutions were made in receptor binding buffer (50 $\mathrm{mM}$ HEPES, $4 \mathrm{mM} \mathrm{MgCl}$, $\mathrm{pH}$ 7.4). All experiments were performed in 96 well assay tubes containing drug dilutions and $75 \mu \mathrm{g}$ porcine striatal membrane protein per tube. Radioligands used were $1 \mathrm{nM}\left[{ }^{3} \mathrm{H}\right] \mathrm{SCH}-23390$ for $\mathrm{D}_{1}$-like binding and $0.15 \mathrm{nM}\left[{ }^{3} \mathrm{H}\right]$ Spiperone for $\mathrm{D}_{2}$-like binding. For $\mathrm{D}_{2}$-like competition experiments, $50 \mathrm{nM}$ ketanserin was added to block $5-\mathrm{HT}_{2 \mathrm{~A}}$ receptors. Nonspecific binding was defined in the presence of $5 \mu \mathrm{M}(+)$-butaclamol. All experiments were incubated at $37^{\circ} \mathrm{C}$ for $30 \mathrm{~min}$ and terminated by rapid filtration with a 96 -well Packard Filtermate cell harvester with ice cold wash buffer $(10 \mathrm{mM}$ Tris, $0.9 \% \mathrm{NaCl})$. Filter plates were dried and Packard Microscint-O $(40 \mu \mathrm{L})$ was added to each filter well. Radioactivity was counted using a Packard Topcount scintillation counter.

Data analysis. GraphPad Prism software (San Diego, CA) was used to generate nonlinear regression curves for radioligand displacement. Hill slopes were fixed and the bottoms of curves were set to nonspecific binding values to generate $\mathrm{IC}_{50}$ values for test compounds. Ki values were calculated by the Cheng-Prusoff equation using the radioligand concentration and previously established porcine striatal $\mathrm{K}_{d}$ values of $0.44 \mathrm{nM}$ and $0.075 \mathrm{nM}$ for $\mathrm{D}_{1}$-like and $\mathrm{D}_{2}$ like binding, respectively.

\section{Acknowledgements}

This work was funded by NIH grants MH42705 (D.E.N.) and MH60397 (V.J.W).

\section{References}

1. Jaber, M.; Robinson, S. W.; Missale, C.; Caron, M. G. Neuropharmacology 1996, 35, 1503.

2. Missale, C.; Nash, S. R.; Robinson, S. W.; Jaber, M.; Caron, M. G. Physiol. Rev. 1998, 78, 189.

3. Sealfon, S. C.; Olanow, C. W. Trends Neurosci. 2000, 23, S34.

4. Kebabian, J. W.; Tarazi, F. I.; Kula, N. S.; Baldessarini, R. J. Drug Discov. Today 1997, 2, 333.

5. Huang, X.; Lawler, C. P.; Lewis, M. M.; Nichols, D. E.; Mailman, R. B. Int. Rev. Neurobiol. 2001, 48, 65.

6. Taylor, J. R.; Lawrence, M. S.; Redmond, D. E., Jr.; Elsworth, J. D.; Roth, R. H.; Nichols, D. E.; Mailman, R. B. Eur. J. Pharmacol. 1991, 199, 389.

7. Williams, G. V.; Goldman-Rakic, P. S. Nature 1995, 376, 572.

8. Goldman-Rakic, P. S.; Castner, S. A.; Svensson, T. H.; Siever, L. J.; Williams, G. V. Psychopharmacology (Berl) 2004, 174(1), 3.

9. Schultz, W. Neuron 2002, 36, 241. 
10. Self, D. W.; Barnhart, W. J.; Lehman, D. A.; Nestler, E. J. Science 1996, 271, 1586.

11. Riggs, R. M.; McKenzie, A. T.; Byrn, S. R.; Nichols, D. E.; Foreman, M. M.; Truex, L. L. J. Med. Chem. 1987, 30, 1914.

12. Brewster, W. K.; Nichols, D. E.; Riggs, R. M.; Mottola, D. M.; Lovenberg, T. W.; Lewis, M. H.; Mailman, R. B. J. Med. Chem. 1990, 33, 1756.

13. Ghosh, D.; Snyder, S. E.; Watts, V. J.; Mailman, R. B.; Nichols, D. E. J. Med. Chem. 1996, $39,549$.

14. Grubbs, R. A.; Lewis, M. M.; Owens-Vance, C.; Gay, E. A.; Jassen, A. K.; Mailman, R. B.; Nichols, D. E. Bioorgan. Med. Chem. 2004, 12, 1403.

15. Michaelides, M. R.; Hong, Y.; Didomenico, S.; Bayburt, E. K.; Asin, K. E.; Britton, D. R.; Lin, C. W.; Shiosaki, K. J. Med. Chem. 1997, 40, 1585.

16. Setler, P. E.; Sarau, H. M.; Zirkle, C. L.; Saunders, H. L. Eur. J. Pharmacol. 1978, 50, 419.

17. Mottola, D. M.; Laiter, S.; Watts, V. J.; Tropsha, A.; Wyrick, S. D.; Nichols, D. E.; Mailman, R. B. J. Med. Chem. 1996, 39, 285.

18. See, for instance, discussion in references 17, 19, 20.

19. Berger, J. G.; Chang, W. K.; Clader, J. W.; Hou, D.; Chipkin, R. E.; McPhail, A. T. J. Med. Chem. 1989, 32, 1913.

20. Snyder, S. E.; Aviles-Garay, F. A.; Chakraborti, R.; Nichols, D. E.; Watts, V. J.; Mailman, R. B. J. Med. Chem. 1995, 38, 2395.

21. Negash, K.; Nichols, D. E.; Watts, V. J.; Mailman, R. B. J Med. Chem. 1997, 40, 2140.

22. Cueva, J. P.; Giorgioni, G.; Grubbs, R. A.; Chemel, B.; Watts, V. J.; Nichols, D. E. J. Med. Chem. 2006, 49, 6848.

23. Fu, P. P.; Unruh, L. E.; Miller, D. W.; Huang, L. W.; Yang, D. T. C. J. Org. Chem. 1985, 50, 1259.

24. Hartman, G. D.; Phillips, B. T.; Halczenko, W. J. Org. Chem. 1985, 50 (14), 2423. 